\title{
A Critical Review of an Epistle Attributed to Idrîs-i Bidlîsî Risâlat al-Khilâfa wa Âdâb al-Salâtîn wa al-Wuzarâ
}

\author{
Vural Genç*
}

This review discusses the authorship of the epistle, entitled Risâlat al-Khilâfa wa Âdâb al-Salâtîn wa al-Wuzarâ, which has been attributed to Idrîs-i Bidlîsî (1457-1520) in various secondary sources and proves that Bidlîsî was not, in fact, the author of this epistle. By revealing the true identity of the writer, this review draws attention to a series of critical mistakes that have resulted from the misattribution of the work to Bidlîsî.

Researchers generally group the works of Idrîs-i Bidlîsî into three different categories: Persian treatises, Arabic treatises, and other treatises attributed to him in secondary sources. These first two groups are well known to researchers because of the existence of actual manuscripts. The absence of manuscript treatises attributed to Bidlîsî in secondary sources, however, results in certain complications. For instance, researchers have misevaluated quoted sources and reproduced them without reference to primary sources and this has led them to misattribute certain works to Bidlîsî. Tuhfe-i Dergâh-ı Âli, Risâle der İbahat-ı Agânî, Haşiye-i Şerh-i Tecrid, Rafizilere Reddiye are just a few of these works. ${ }^{1}$ Some of the works cited in secondary sources are taken to be treatises on their own, when in actuality they are not stand-alone works. Others are classified as authored by Bidlîsî on the basis of only one sentence taken from a secondary source, with no material evidence in support. ${ }^{2}$

* Istanbul University

1 See the other epistles attributed to Bidlîsî, İdris-i Bidlîsî, Selim Şah-nâme, trans. Hicabi Kırlangıç, Ankara 2001, p. 21; Muhammed İbrahim Yıldırım, İdris-i Bitlîsî Heşt Behişt VII Ketibe: Fatih Sultan Mehmed Devri 1451-1481, TTK Yay., Ankara 2013, pp. xlviii-xlix.

2 Tuhfe-i Dergâh-ı Âlî and Risâle der İbâhat-ı Agânî exemplifies this case. For debates on the latter please see, Vural Genç, “Acem'den Rum'a”: İdris-i Bidlîsînin Hayatı, Tarihçiliği ve Heşt Behiştin 
An example of an epistle misattributed to Bidlîsî in recent scholarly works is Risâlat al-Khilâfa wa Âdâb al-Salâtîn wa al-Wuzara. ${ }^{3}$ In recent scholarly publications, the epistle in question has been presented as one of Bidlîsîs. In Ebru Sönmez's book titled Idris-i Bidlisi Ottoman Kurdistan and Islamic Legitimacy it was used substantively as a primary source, resulting in significant errors in argument ${ }^{4}$ while in Nabil al-Tikriti's recently published paper entitled 'Idris-i Bidlisi's 1513 treatise on caliphal and sultanic protocols: Risâlat al-Khilâfa wa Âdâb alSalâtîn wa al-Wuzarâ," the epistle in question was simply overviewed. In her third chapter, dealing with the image of the Ottoman caliph-sultan and the notion of the ideal ruler during the period of Selim I and Süleyman the Lawgiver, Sönmez suggests that Bidlîsî wrote the epistle in question prior to Selim's eastern campaign. His objective, according to Sönmez, was to depict the Ottoman political Sunni identity, which was shaped in the sixteenth century, and to assert that the Ottomans were the sole protectors of the Islamic world. Sönmez also argues that the Ottoman-Safavid conflict afforded Bidlîsî the opportunity to articulate his political thinking. ${ }^{5}$ She adds that in 1512 , when this epistle was completed in Cairo, the fight for the throne was ongoing among Bayezid's princes and that a similar contestation was taking place throughout the Islamic world between the Ottomans, the Safavids, and the Mamluks. Accordingly, Sönmez claims that in light of this political context Bidlîsî took it upon himself to create a new image of the Ottoman caliph-sultan by authoring this epistle. ${ }^{6}$

In his recently published paper, Nabil al-Tikriti claims that the epistle in question was written by Bidlîsî. ${ }^{7}$ Moreover, he asserts that it was one of the three major epistles presented to young prince Selim during the turbulent period in which he competed against his brothers for the Ottoman throne. Al-Tikriti explains that the epistle asserts the superiority of the young prince over his brothers

II. Bayezid Kısmı (1481-1512)" (unpublished Ph. D. dissertation), İstanbul University Institute of Social Sciences, 2014, p. 959.

3 Risâlat al-Khilâfa wa Âdâb al-Salâtîn wa al-Wuzarâ, Istanbul University Nadir Eserler Library, numbered F.1228.

4 Ebru Sönmez, Idris-i Bidlisi: Ottoman Kurdistan and Islamic Legitimacy (İstanbul: Libra Kitap 2012).

5 Ibid., pp. 129,137.

6 Sönmez, Idris-i Bidlisi: Ottoman Kurdistan and Islamic Legitimacy, p. 160.

7 Nabil Al-Tikriti, "Idris-i Bidlisi's 1513 treatise on caliphal and sultanic protocols", New Trends in Ottoman Studies: Papers presented at the 20th CIÉPO Symposium Rethymno, 27 June-1 July 2012, M. Sariyannis, G. Aksoy-Aivali, M. Demetriadouet al. (eds.) (Rethymno: University of Crete, 2014), pp. 741-756. 
and reflects hallmarks of the nasîhatnâme literature, also known as "mirror for princes." ${ }^{8}$ Furthermore, he alleges that as Bidlîsî witnessed Selim's rise to power, he began to write a nasîhatnâme-themed epistle in an attempt to prove his literary talent and political savvy to the new Sultan's court. He adds that after Selim accepted the work, Bidlîsî went on to formulate the epilogue of his magnum opus, Hasht Behisht, according to the worldview of the new sultan. ${ }^{9}$ Moreover, he argues that the epistle, which he inappropriately describes as comprehensive, was submitted to the Sultan from Mecca as an ornate gift, in an effort to pave the way for Bidlîsîs receipt of the Sultan's patronage.

Bidlîsîs use of both Persian and Arabic in the same text also draws Al-Tikriti's attention. He claims that Bidlîsîs linguistic choices reflect deliberate objectives: to demonstrate his multi-lingual literary talent and to make a favorable impression on Selim. As evidence in support of these claims, Al-Tikriti quotes an ambiguous verse, which Sharaf Khân attributed to Bidlîsî, in which the alleged author displayed his abilities to Shâh Ismâil in both Arabic and Persian. ${ }^{10}$ Additionally, he asserts that Bidlîsis's purpose in formulating certain Sunni arguments was to substantiate his own side, and that the epistle was written with the purpose of guiding Selim in his fight to secure Rum's borderland against rebellions. ${ }^{11}$ Subsequently, by paying attention to each part of the epistle, Bidlîsî portrays Selim as an ideal ruler and formulates a counsel on rulership (nasîhatnâme). According to Al-Tikriti, in order to enhance the image of "The Shadow of God on Earth," a concept, which was formulated for Selim, Bidlîsî employed stories of SolomonBalqis. ${ }^{12}$ Furthermore, he argues that the narratives Bidlîsî wrote regarding tax collection for the purpose of sustaining rulership can be read as a refutation of Korkud's assertion on this matter. In the last part of the epistle, covering military organisation, Al-Tikriti asserts that in referencing Alexander the Great and Cenghis Khan's military traditions, Bidlîsî endeavored to prove to Selim that he could be an able military counselor. The narrative of Iskender-i Zûl-qarnayn, according to him, was a vehicle for Bidlîsî to legitimize Selim's violence against the

8 For two other epistles -Anonimous Risala fi sharh qasida julus Sultan Salim Khanand Shams al-Dîn Jahramî̀s Risala siyasiya bara-yi Sultan Salîm- see. Al-Tikriti, "Idris-i Bidlisi's 1513 treatise on caliphal and sultanic protocols", p. 742.

9 Al-Tikriti, "Idris-i Bidlisi's 1513 treatise on caliphal and sultanic protocols", pp. 743-744.

10 Ibid., p. 745.

11 Ibid., p. 746.

12 Ibid., pp. 749-750. 
Qizilbash rebellions and Shâh Ismâiil. ${ }^{13}$ Lastly, he adds that although the epistle was not a masterpiece in its genre, after having been accepted by Selim, its author was summoned to the court where the Battle of Chaldiran gave Bidlîsî a crucial opportunity to serve as mediator between the Sultan and Kurdish notables. In this respect, therefore, the epistle served a real purpose. ${ }^{14}$

Whereas Sönmez states that Bidlîsî penned the epistle in question while he was in Cairo, Al-Tikriti claims instead that the epistle was written in Mecca. These two conflicting statements lead us to a vital question: is the epistle, indeed, Bidlîsîs? Thorough research on the epistle under investigation has helped to put Bidlîsîs authorship in question.

A sentence in the prologue- "God sent him to earth as Caliph when heretics emerged in the Rum borderland. He is Selimşah, King of Kings" - clarifies that this epistle was presented to Selim. ${ }^{15}$ According to its epilogue, the work was presented in February-March of 1513. The epistle consists of 43 folios and includes three parts. While it is not as detailed as the typical nasîhatnâme, it can nevertheless be categorized as falling within the scope of nasîhatnâme literature. The first section of the epistle, written in Arabic, deals with Maliki and Shafi jurisprudence (usîl al-fiqh) and the necessity of the Caliphate, and uses Quranic verses as evidence to corroborate arguments. The second section is bilingual, beginning in Arabic and continuing with Persian stories. It includes the concept of justice of kings and the etiquette of their viziers ('adli'l-umarâ wa adabu vuzarâibim), two topics, which are more consonant with the title of epistle. The main emphasis of this section is on the concept of the just ruler and the discussion is supported with reference to the stories of Solomon and his vizier Âsaf. Under the title of tertîb-i 'asâkir, the third section focuses on military organization and campaign preparation such as making armor, blocking roads, and taking wealthy people on campaign. All of these were practices dating to the time of Alexander the Great and Cenghis Khân. It is clear that in highlighting his knowledge of military experiments, as Al-Tikriti accurately observes, the author aimed to attract Selim's attention. At the end of this section, the author argues that a counselor of rulers is necessary, referencing the examples of Ilkhanid ruler Hülagü and his counselor Nasir al-DînTusî.

13 Ibid., p. 754.

14 Ibid., p. 756.

15 Risâlat al-Khilâfa wa Âdâb al-Salâtîn wa al-Wuzarâ, f. 2a. 
The only reference to Bidlîsîs authorship of this epistle is a note, written by a reader, stating: "as Ali Emiri attested, this epistle belongs to Bidlîsî." ${ }^{16}$ This note is attributed to Ali Emiri and is located in the first folio of the epistle. Several pieces of evidence exist with which to evaluate the note's veracity. In the prologue of each of Bidlîsîs treatises he provides brief autobiographical information. In the epistle under question, however, this information is omitted. The epistle's slapdash style, simple language, lack of eloquence, mixed Arabic-Persian text, and the abrupt interruption of the epilogue are further characteristics not found in Bidlîsîs works. While the epistle does reflect certain aspects of nasîhatnâme, it does not resemble Bidlîsîs sophisticated treatises in the nasîhatnâme genre, such as Mir'ât al-Jamâl and Qânûn-i Shahinshâh. Simple grammatical errors or poor wording, for example, suggest that the author was an amateur, unlike Bidlîsî. ${ }^{17}$ As a matter of fact, in folio 8a, the author of Risâlat al-Khilâfa wa Âdâb al-Salâtîn wa al-Wuzarâ identifies himself as Khotanî ${ }^{18}$ in a sentence written in mixed TurkishArabic. According to this information, it is reasonable to conclude that the author of this epistle is in fact a man by the name of Khotanî. ${ }^{19}$ Besides the language and style of the epistle, the content itself also calls into question Bidlîsîs authorship. First, the author states that when he heard about the Selim's march to Edirne he told a fortune through the Attar's Mantiq al-Tayr in front of the congregants at Friday prayer. ${ }^{20}$ This statement indicates that the author was close enough to Selim to be aware of his activities. Second, that the epistle was penned in Zilhijja 918/February-March 1513 also denotes that it cannot have been penned by Bidlîsî. In far off Mecca, Bidlîsî cannot have possibly known of Selim’s every movement. While observing Selim's march for the throne, Khotanî, the author of Risâlat al-Khilâfa wa Âdâb al-Salâtin wa al-Wuzarâ, must have sought Selim's patronage through the production and presentation of a simple epistle.

16 Ibid.,f. 1a.

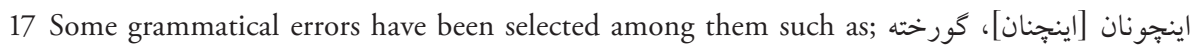
Except these, the non-use of vav-ı ma'dûle in writting of the verbs such

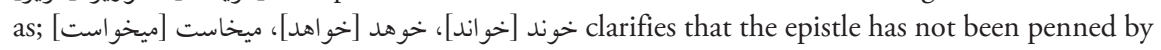
Bidlîsî.

18 There is no information about Khotanî in both inamat defters and şuara tezkeres.

من فصاحت برله مدحكى اكوب خون كخكلكده خطايى لفظدن تكرار اولوب انا فقير اضعف العباد ختنى 19

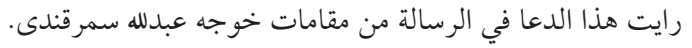

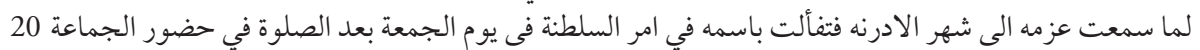

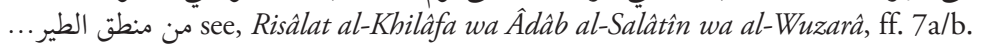




\section{EPISTLE ATTRIBUTED TO IDRÎS-I BIDLÎS Î}

A more careful and rigorous analysis of Bidlîsîs intellectual life and his extant corpus, with particular attention to his eloquent chancery style, could have prevented scholars from misattributing authorship and consequently constructing misleading arguments concerning the life and work of Bidlîsî. 